\section{Postharvest \\ Water Intake and \\ Decay of \\ Tomatoes}

\author{
Robert K. Showalter ${ }^{1}$
}

Additional index words. Lycopersicon esculentum, water infiltration, bacterial infiltration, Erwinia carotovora

Summary. Serious, postharvest decay losses occurred in tomatoes when water in which they were submerged was cooler than the fruit. Tomatoes have extensive intercellular air spaces, a heavily cutinized epidermis, and no stomatal openings. When tomatoes with unbroken skins were submerged in packinghouse dump tank water of lower temperatures, the internal air contracted and water plus decay organisms were drawn into the fruits through the stem scar. Heating dump tank water has been successful in limiting this decay problem.

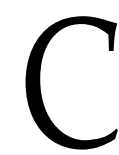

ommercial tomato production began in Florida between 1880 and 1900, and has expanded to more than 60,000 acres $(24,282 \mathrm{ha})$ in southern Florida for harvests during fall, winter, and spring. Production was initiated in western Florida in 1977 on 650 acres (263 ha) for midsummer harvest and expanded to more than 4000 acres ( 1619 ha) by 1990 (Florida Agricultural Statistics Vegetable Summary). Dramatic improvements in postharvest handling have occurred during this century, but marketing losses still range from $14 \%$ to $70 \%$ from all causes, with major losses due to decay (Harvey, 1978). Tomatoes for fresh market and processing have been submerged in water as part of the harvesting and sorting operations to reduce bruising injuries and clean the fruit. Chlorine is generally added to the water for decay control. Extensive literature provides a historical account of the role that horticultural technology has played in making the tomato such a widely ap-

Department of Horticultural Sciences, IFAS, University of Florida, Gainesville, FL 32611.

${ }^{1}$ Professor Emeritus. preciated food (Tigchelaar and Foley, 1991).

The problem. Severe, postharvest decay losses occurred in the western Florida tomatoes during the warm, June and July harvests of 1977 and 1978. The tomatoes were hand-harvested, hauled in bulk bins to packinghouses, dumped into tanks of water, washed, and carefully graded to remove any fruit with skin cracks, bruises, or decay symptoms. The field and packinghouse handling methods were similar to those used in southern Florida during the fall, winter, and spring harvests, but chlorination of the water in dump tanks and washers did not control the decay in midsummer. Tomatoes with no skin breaks developed bacterial soft rot or sour rot beneath the stem scar 1 or 2 days after harvest.

Tomato fruit characteristics. Tomatoes are one of several large fleshy fruits that have extensive intercellular air spaces interconnected among the loosely bound ceils. In apples, pears, and citrus the air spaces are connected with stomata in the epidermis for exchange of water vapor and gasses such as oxygen and carbon dioxide. However, mature tomatoes are characterized by a relatively thick external wall with a heavily cutinized epidermis that has no stomatal openings. The exchange of water and gases in tomatoes occurs almost entirely at the stem scar. The impermeability of noninjured tomato skins can be demonstrated by submerging a tomato in water of a higher temperature and observing the expanded internal air bubbling exclusively from the stem scar and corky ring.

When tomatoes are submerged in water of a lower temperature, the internal air contracts and water is drawn into the fruit through the stem scar or any surface not covered by cuticle. The tomato skin is an effective barrier against most diseases as long as it remains unbroken. Growth cracks, bruises, and sand scarring frequently permit the entrance of decay organisms.

Warm temperatures increase decay. Weather conditions influence the prevalence of tomato market diseases such as bacterial soft rot, which often originate in the field and are present on the tomatoes when harvested. Bacterial soft rot develops most rapidly at about 30C (86F). Loads of tomatoes often waited at the packinghouses for 
varying periods before unloading. When held in shade for $1 \mathrm{~h}$, tomato temperatures averaged 28 to $35 \mathrm{C}$, but, after $1 \mathrm{~h}$ in the sun, tomato temperatures averaged 42 to $50 \mathrm{C}$.

Water infiltration and decay. The effects of tomato and water temperatures on infiltration were measured with tomatoes carefully harvested from fields in western Florida during regular harvesting. Water intakes equaled $1 \%$ to $4 \%$ of the fruit weight when the water was 11 to $33 \mathrm{C}$ colder than the tomatoes (Showalter, 1979). Infiltration of $3 \%$ to $4 \%$ water resulted in some watersoaked areas near vascular tissues and slight skin breaks. Research in California showed that freshly harvested, warm tomatoes immersed in cold water resulted in a substantial number of cracked fruit due to water intake, but incidence of decay was not mentioned (Studer and Kader, 1977).

Research at the Univ. of Florida has shown that inoculation of uninjured tomatoes by decay-producing bacteria and fungi occurs through the stem scar and corky ring (Bartz and Showalter, 1981). Most tomatoes inoculated by infiltration showed no initial external symptoms, but decay spread rapidly inside the fruit. When the intake water was contaminated with Erwinia carotovora, the resulting decay followed the same pathway as the water beneath the stem scar. Bacteria entered into mature green or ripe tomatoes when warm fruit were immersed into cooler water. Entrance of bacteria occurred before significant weight increases and, as the temperature difference between warm tomatoes and cooler water was increased, so did the intake of bacteria and water into the fruit. Infiltration was also increased by increasing the depth of tomato submersion in water (Bartz, 1982).
Discussion. When a pathogen penetrates inside a fruit, the environment is ideal for growth, with bacterial ooze apparent within $24 \mathrm{~h}$. The infected fruit disintegrate, and they can infect adjacent healthy tomatoes within another 24-h period. Infiltration must be prevented not just limited in tomato packinghouses. Inadvertent inoculation by infiltration results in much greater postharvest loss than inoculation through small injuries on the fruit surface. Fruits with large injuries are normally culled out during grading, and those without skin breaks would not be inoculated.

Recommendations for decay control. When tomatoes rotted on the inside without surface injury, it was concluded that chlorine did not have time to inactivate all the organisms in the water before they entered the tomatoes (Showalter and Bartz, 1979). Heating dump tank water 5C higher than the highest tomato temperatures has reduced the infiltration, and has been successful in limiting this decay problem (Sherman et al., 1981).

The following factors influence tomato decay during harvesting and packinghouse handling.

Weather conditions prior to harvest strongly influence the prevalence of postharvest decay organisms on harvested tomatoes.

Tomatoes arriving at packinghouse dump tanks vary widely in temperature with season and exposure to sun or shade. Keeping harvested fruit in shade requires less dump tank water heating in order to exceed the warmest tomato temperatures.

Chlorination of packinghouse water does not disinfect contaminated tomatoes, but it does reduce the number of organisms capable of inoculating healthy fruit.

If tomatoes are immersed to a depth of $91 \mathrm{~cm}$ (36 inches) in dump tanks for 2 to 5 rein, the water pressure may cause rapid infiltration with contaminated water. Minimize the depth to which tomatoes are submerged to $<61 \mathrm{~cm}$ (24 inches) when dumped, and then maintain them as a single layer of fruit.

Longer periods of time in the dump tank increase the chances of tomato inoculation, especially with increasing depth of submersion.

Temperature regulation of dump tank water should be a companion control measure with chlorination in preventing postharvest decay.

\section{Literature Cited}

Bartz, J.A. 1982. Infiltration of tomatoes immersed at different temperatures to different depths in suspensions of Enwinia carotovora subsp. carotovora. Plant Dis. 66:302-306.

Bartz, J.A. and R.K. Showalter. 1981. Infiltration of tomatoes by aqueous bacterial suspensions. Phytopathology 71:515 518.

Harvey, J.M. 1978. Reduction of losses in fresh market fruits and vegetables. Annu. Rev. Phytopathol. 16:321 341.

Sherman, M., R.K. Showalter, J.A. Bartz, and G.W. Simone. 1981. Tomato packinghouse dump tank sanitation. Florida Coop. Ext. Serv. Fact Sheet VC-31.

Showalter, R.K. 1979. Postharvest water intake by tomatoes. HortScience 14:125. (Abstr.)

Showalter, R.K. and J.A. Bartz. 1979. Postharvest water intake and decay of tomatoes. Citrus and Veg. Mag. 43(4):7,28.

Studer, H.E. and A.A. Kader. 19761977. Handling tomatoes in water. Annu. Rpt. Fresh Market Tomato Res. Prog. Fresh Market Tomato Adv. Board, Bakersfield, Calif.

Tigchelaar, E.C. and V.L. Foley. 1991. Horticultural technology. HortTechnology 1:7 16. 